\title{
Antioxidant Potential of the Propolis of Melipona Quadrifasciata as a Preservative for Craft Beer
}

\author{
Galgowski, C.; Fischer, B.; Simionattoa, E. L.; Guedes, A.; Cordova, C. M. M.*
}

Rev. Virtual Quim., 2019, 11 (6), 1872-1881. Data de publicação na Web: 2 de janeiro de 2020

http://rvq.sbq.org.br

\section{Potencial Antioxidante da Própolis de Melipona Quadrifasciata como Conservante de Cerveja Artesanal}

\begin{abstract}
Resumo: Propolis é uma mistura complexa estudada devido à suas propriedades biológicas, mas frequentemente aquela produzida pela abelha Apis melifera. Poucos estudos foram realizados, proporcionalmente, com própolis de abelhas nativas brasileiras, uma vez que se sabe que a composição química da própolis varia de acordo com a espécie de abelha que a produz. O potencial antioxidante do extrato de própolis da abelha Melipona quadripasciata já foi demonstrado. Apesar do seu relativamente baixo teor de compostos fenólicos e flavonóides, tem a capacidade de redução do potencial e inibição do radical livre DPPH e inibição da peroxidação lipídica. Assim, buscou-se avaliar o potencial de diferentes frações do extrato hidroalcoólico dessa própolis de abelha nativa incorporada em amostras de cerveja de baixa fermentação, para determinar se poderia eventualmente aumentar a vida de prateleira da bebida, melhorando sua qualidade. Os compostos da própolis foram extraídos com solventes de diferentes polaridades, secos e adicionados às amostras de cerveja em diferentes concentrações. Todas as amostras adicionadas de própolis inibiram a oxidação sem alterar as características organolépticas da cerveja. O uso de própolis como conservante de cervejas artesanais brasileiras, uma vez bem fundamentada, pode agregar valor significativo à cadeia produtiva da apicultura no país. Notavelmente, os compostos extraídos na fração diclorometano deste tipo de própolis parecem ser promissores, uma vez que até melhoram a percepção da cerveja. As interações químicas e compostos resultantes da adição de própolis à cerveja merecem ser melhor estudados.
\end{abstract}

Palavras-chave: antioxidante; cerveja artesanal; conservante; produtos naturais; propolis; Melipona quadripasciata.

\begin{abstract}
Propolis, especially from Apis melifera, is a complex matrix that has attracted attention for its many biological properties. Relatively few studies have been done on the propolis of Brazilian native bees. The chemical composition of propolis varies according to the bee species producing it. The antioxidant potential of the propolis made by the stingless bee Melipona quadripasciata has already been demonstrated. Despite its relatively low content of phenolic and flavonoid compounds, it has the capacities of reduction potential, the inhibition of the free radical DPPH and the inhibition of lipid peroxidation. Thus, we sought to evaluate the potential of incorporating different fractions of the hydroalcoholic extracts of this native bee propolis into samples of a low fermentation beer to determine its potential for increasing the shelf life of the beverage and improving quality. Propolis compounds were extracted with solvents of different polarities, then dried and added to beer samples at different concentrations. All samples with added propolis showed inhibited oxidation without changes to organoleptic characteristics. The use of propolis as a preservative for Brazilian craft beers, once well-founded, could add significant value to the production chain of beekeeping in the country. Notably, the compounds extracted in the dichloromethane fraction of this type of propolis seem to be promising, since they improved the perception of beer over time. The chemical interactions and compounds resulting from the addition of propolis to beer deserve further study.
\end{abstract}

Keywords: antioxidant; craft beer; preservative; natural product; propolis, Melipona quadripasciata

\footnotetext{
* Universidade de Blumenau - FURB, Departamento de Ciências Farmacêuticas, Campus 3, Rua São Paulo 2171, CEP 89030-001, Blumenau-SC, Brasil.

M cmcordova@furb.br DOI: $10.21577 / 1984-6835.20190130$
} 


\section{Antioxidant Potential of the Propolis of Melipona Quadrifasciata as a Preservative for Craft Beer}

\section{Caroline Galgowski, ${ }^{a}$ Bruna Fischer, ${ }^{b}$ Edésio Luis Simionatto, ${ }^{a, c}$ Alessandro Guedes, ${ }^{d}$ Caio Mauricio Mendes de Cordova ${ }^{a, d, *}$}

a Universidade de Blumenau, Programa de Pós-graduação em Química, Campus 1, Rua Antônio da Veiga 140, CEP 89030-903, Blumenau - SC, Brasil.

${ }^{\text {b }}$ Universidade de Blumenau, Curso de Biomedicina, Campus 3, Rua São Paulo 2171, CEP 89030-001, Blumenau-SC, Brasil.

c Universidade de Blumenau, Departamento de Química, Campus 3, Rua São Paulo 2171, CEP 89030-001, Blumenau-SC, Brasil.

d Universidade de Blumenau, Departamento de Ciências Farmacêuticas, Campus 3, Rua São Paulo 2171, CEP 89030-001, Blumenau-SC, Brasil.

cmcordova@furb.br

\section{Introduction}

2. Material and Methods

\section{Results}

\section{Discussion}

5. Conclusion

\section{Introduction}

Studies of beer stability are carried out in the preliminary stages of the commercialization of a new product or when changes are made to the manufacturing process. Several changes can occur in beverages, even after bottling. Transport and storage are critical processes regarding beverage degradation. ${ }^{1,2}$

The biological instability of beer involves contamination by bacteria, yeasts and micellar fungi. Contamination by microorganisms is always a risk. However, beer is not a very favorable medium for microbial growth due to its low pH $(\approx 4)$ and the presence of ethanol in various concentrations. However, raw materials like barley may contain fungi of the genus Fusarium that can release mycotoxins and lead to beer deterioration. From the microflora found in beer, gram-positive bacteria that produce lactic acid are the most feared. In addition to being a potential spore in beer, lactic bacteria are difficult to detect, recover and identify. ${ }^{3}$

Stored beer is likely to lose, over time, brightness and gain a certain 'haze'. ${ }^{4}$ The balance 
between flavonoids, polyphenols and sensitive proteins dictates the colloidal stability of the product. ${ }^{5}$ The stability of taste depends primarily on the oxygen contained in the beverage package. The adverse effects of oxidation on the taste of beer in the finished product are known. Over time, some brewing bisulfites or other antioxidants such as ascorbic acid have been added to beer prior to bottling to provide protection against oxygen; these can improve flavor stability. ${ }^{5}$

Ultraviolet (UV) rays accelerate the oxidation of fatty acids, which produce unpleasant odors and flavors. The presence of light may increase the rate of the oxidation of beer, because when exposed to light, the hops' aromatic compounds degrade and combine with the sulfur compounds, creating unpleasant aromas. Certain compounds, such as tetra (isomerized hops), are essential for good beer quality, so it is also important to add them to the drink for greater resistance to light. ${ }^{6,7}$

The best way to define shelf life is to understand the changes that occur in product quality over time. The estimated validity of a product is a guarantee that a product sent to the market is safe and has the desired quality until the act of consumption. ${ }^{8,9}$ The interaction of intrinsic and extrinsic factors may inhibit or stimulate several processes that limit the life span of a beverage. ${ }^{10}$

Propolis is a resinous substance produced by bees from the exudates of plants that they collect in their jaws. It is considered a rich and complex matrix, since it has secondary metabolites of diverse botanical origins. ${ }^{11}$ Propolis has attracted a lot of attention, both commercial and scientific, ${ }^{12}$ because in addition to its medicinal properties, propolis has been widely used for dietary supplements, food preservatives, germicides and insecticides. ${ }^{13}$ Japan is the largest buyer of Brazilian propolis, mainly for food and functional beverages, ${ }^{14}$ because Brazilian propolis is considered to have a high degree of purity and attractive organoleptic properties, in addition to its wellestablished therapeutic properties. ${ }^{15}$

Green propolis gained market preference due to its physico-chemical characteristics, its pleasant odor and its color that ranges from yellowish green to dark green. The main characteristic of green propolis is its high content of cinnamic acid derivatives, sesquiterpenes, diterpenes and pentacyclic triterpenes. Although flavonoids are not the main constituents, some representatives of this class are found in this type of propolis. ${ }^{16}$ Flavonoids are a group of secondary metabolites with many therapeutic properties. ${ }^{17} \mathrm{~A}$ key role of flavonoids is their ability to stop the cascade effect of naturally occurring reactive oxygen species in human cells, thus making them effective antioxidants. ${ }^{18}$ Propolis from temperate zones such as Brazil are rich in flavonoids, as well as phenolic acids and their esters. ${ }^{19}$ Terpenes are a group of secondary metabolites with more than 30,000 different known molecules that are present in plants, bacteria, fungi and some marine animals. ${ }^{20}$ In propolis, terpene compounds are also considered volatile constituents. Although they represent only $10 \%$ of the propolis components, they contribute to its resinous and organoleptic characteristics and pharmacological effects and can be used to distinguish samples of low and high quality. ${ }^{21}$ In general, terpene molecules have been widely studied as sources of antioxidants: because of their chemical structure of double bonds, they are able to block the cascade of ROS formation. ${ }^{20}$

In a previous study with samples of propolis from the native bee Melipona quadrifasciata, researchers created a profile for the aqueous and hydroalcoholic extracts of the green/yellow propolis that included phenols, tannins, flavonoids, steroids, triterpenes, flavones, flavonols and xanthones. $^{22}$

Recent studies have shown the antioxidant potential of different fractions of hydroalcoholic extracts and the methanol extract of Melipona quadripasciata propolis. The reducing potential, in ascorbic acid equivalents per $100 \mathrm{~g}$ of sample, was best with the ethyl acetate fraction $(127.83 \pm 1.45 \mathrm{mg}$ AA $100 \mathrm{~g}-1)$, followed by the methanolic extract and the insoluble fraction. In the DPPH free radical inhibition assay, the methanolic 
extract presented better activity $(151.37 \pm 7.92$ $\mu \mathrm{g} \mathrm{L}-1)$. In the lipid peroxidation inhibition assay, the methanolic extract, the hydroalcoholic extract and the ethyl acetate fraction have been highlighted. ${ }^{23}$ In summary, antioxidant trials have highlighted the methanolic extract, which probably has a higher content of phenolic compounds and flavonoids and shows greater reduction potential, DPPH free radical inhibition capacity and inhibition of lipid peroxidation.

The aqueous extracts of propolis often have stronger antioxidant activities than those of the antioxidants vitamin $\mathrm{C}$ and vitamin $\mathrm{E}$. These extracts are also superior to BHT, which is commonly used in tests as a positive control to inhibit lipid peroxidation. ${ }^{24}$

Thus, we sought to evaluate the potential of incorporating different fractions of the propolis hydroalcoholic extract of this native bee into beer samples of low fermentation to evaluate if this incorporation can eventually increase the shelf life of the beverage, thereby improving its quality.

\section{Material and Methods}

Beer samples: We used Pilsen-style lowfermentation beer samples obtained immediately after the final production stage (bleaching), shortly before packaging and without the addition of ascorbic acid as a preservative.

Preparation of the propolis extracts: the propolis of the Mandaçaia bee (Melipona quadrifasciata) was collected in the city of Blumenau, SC, Brazil, and analyzed. 500 $\mathrm{mg} / \mathrm{mL}$ of the hydroalcoholic extract $(\mathrm{EBH})$ was obtained by maceration with $70 \%$ ethanol in a dark chamber for 7 days, followed by vacuum filtration and evaporation of the solvent in a rotary evaporator under reduced pressure. The extract was resuspended in water and partitioned through liquid-liquid fractionation using n-hexane, dichloromethane, ethyl acetate and nbutanol. Each obtained fraction was subjected to rotary evaporator drying until constant weight was obtained for complete evaporation of the solvent; they were then maintained at $4{ }^{\circ} \mathrm{C}$ in glass flasks.

Fluorescent light tests: In order to simulate the impact of light in supermarkets on the stability of beer, we simulated a market shelf in a refrigerator with two $18 \mathrm{~W}$ fluorescent light bulbs at a temperature of $8 \circ \mathrm{O}( \pm 2)$. The behavior of the beer was studied in different groups, one for each type of propolis fraction, with three different amounts (15, 45 and 75 $\mathrm{mg}$ ) dissolved in $300 \mathrm{~mL}$ of beer, resulting in propolis concentrations of $0.05 \mathrm{~g} / \mathrm{L}, 0.15 \mathrm{~g} / \mathrm{L}$ and $0.25 \mathrm{~g} / \mathrm{L}$. There was also a group without the addition of propolis. All were packaged and closed in amber bottles as for sale. The bottles were placed for $42 \mathrm{~h}, 84 \mathrm{~h}, 126 \mathrm{~h}$ and $168 \mathrm{~h}$ in the chamber with fluorescent light. These exposure times correspond to two, four, six and eight months of shelf life, respectively. ${ }^{2}$ After the test, the products were taken for sensory analysis, as was the fresh product (maintained in dark at $6 \stackrel{\circ}{ } \mathrm{C}$ after its production), and an aliquot was reserved to test antioxidant activity in vitro.

Sensory analysis: the analysis was performed using the 165/IV acceptance test with a hedonic scale of 9 points, according to the methodology proposed by the Adolfo Lutz Institute, São Paulo, Brazil. ${ }^{25}$ The following attributes were evaluated: appearance, flavor, aroma and overall assessment, on a scale from 1 to 9 , from 'extremely disagreeable' to 'extremely liked'. Six untrained random evaluators of both sexes were recruited with inclusion criteria being at least 18 years old, liking beer and agreeing to not drive for at least 60 minutes after the end of the analysis. Those who had allergies to any ingredients, including propolis and gluten, were excluded. For each evaluator, $30 \mathrm{~mL}$ of beer was served at a temperature of approximately $6{ }^{\circ} \mathrm{C}$ in transparent plastic cups. Mineral water was imbibed between each sample to avoid interference in the analysis. The tasting took place between 10 a.m. and 12 p.m. in a room at $20 \stackrel{\circ}{ } \mathrm{C}$ with no odor or natural light. Each taster was not allowed to see the others' faces to prevent any influence on the results. 
Antioxidant activity test with betacarotene: this method is based on the inhibition of lipid peroxidation through the beta-carotene/linoleic acid model. ${ }^{26}$ An emulsion was prepared with $3.0 \mathrm{mg}$ of $\beta$ carotene, $1 \mathrm{ml}$ of chloroform, $45 \mathrm{mg}$ of linoleic acid and $215 \mathrm{mg}$ of tween-80. The chloroform was evaporated in a hood for 4 minutes at a temperature of $45^{\circ} \mathrm{C}$. Six $\mathrm{mL}$ of distilled water was added to the resulting mixture through stirring to make an emulsion. This was then added to a $100 \mathrm{~mL}$ volumetric flask with $0.01 \mathrm{M}$ hydrogen peroxide. An aliquot $(4 \mathrm{~mL})$ of the emulsion was added to tubes containing $0.2 \mathrm{~mL}$ of the sample solutions (beer). As a positive control, a solution of di-tert-butyl methyl phenol (BHT) at a concentration of 1000 ppm was used. As a negative control, a mixture was prepared with $4 \mathrm{ml}$ of the emulsion mentioned above and $0.2 \mathrm{ml}$ of methanol. For the spectrometric blank, an emulsion prepared as described above was used, but without $\beta$-carotene. All tubes were incubated in a water bath at 37 ㅇ C and the absorbances of the solutions were determined using a spectrophotometer at $470 \mathrm{~nm}$ beginning at time zero, then every 30 minutes up to 180 minutes. The antioxidant activity (AA) determined by this test was calculated using the equation: $A=$ $100[1-(\mathrm{A} 0-\mathrm{At}) /(\mathrm{A} 00-\mathrm{A} 0 \mathrm{t})]$; where $\mathrm{AO}=$ absorbance of the sample at time zero, $A t=$ absorbance of the sample after 180 minutes, $\mathrm{A} 00=$ absorbance of the negative control at time zero and $\mathrm{AOt}=\mathrm{absorbance}$ of the negative control after 180 minutes.

Statistical analysis: The data from the oxidation test were analyzed using a one-sided Student's t-test with MS Excel (Microsoft, Redmond, Washington, USA) and the data of the sensory evaluation were submitted to analysis of variance (ANOVA), with a confidence level of $5 \%$, using the ezAnova software (Chris Rorden (C 2007).

\section{Results}

The results of the inhibition of lipid peroxidation showed that the beer without the addition of propolis, whether submitted to the light chamber (CCL) or in the dark (CSL), oxidized beta carotene, though with a borderline statistical significance compared to $\mathrm{BHT}$, a strong antioxidant $(P=0.06-0.08)$. All beer samples with added propolis inhibited oxidation, though with no significant difference compared to BHT. It was also observed that the beer samples with the extracted ethyl acetate and butanol compounds showed borderline reductions in oxidation $(P=0.05-0.06)$ in relation to the CCL sample, and the first presented an inhibition of oxidation in relation to the CSL sample $(P=0.0478)$. The extracted dichloromethane and butanol compounds presented a borderline reduction in oxidation compared to the CSL sample $(P=$ 0.05 to 0.06 ). Table 1 presents the results of the beta-carotene oxidation inhibition test. In sum, beer without propolis presented oxidant compounds and, notably, beer with added extracted ethyl acetate, dichloromethane and butanol compounds from propolis was protected from oxidation, thus improving its shelf life.

In relation to the organoleptic characteristics, we observed that the extracted aqueous (Faq), dichloromethane ( $\mathrm{Fdcm})$, ethyl-acetate (Fact) and butanol (Fbut) compounds did not modify the perception of the quality of the beer analyzed. EBH at $45 \mathrm{mg}$ apparently altered appearance, taste and aroma at $82 / 126 \mathrm{~h}$, but not at $186 \mathrm{~h}$, which may be due to bacterial or fungal contamination during the handling of this specific sample. The EBH $75 \mathrm{mg}$ sample also presented the same type of alteration as the sample with $15 \mathrm{mg}$ of added hexane fraction. Interestingly, the sample with $45 \mathrm{mg}$ of added extracted water compounds showed improvement in aroma at $126 \mathrm{~h}$, but not in earlier or later periods. Likewise, the sample with $15 \mathrm{mg}$ of added extracted dichloromethane compounds showed improvements in all aspects at $84 \mathrm{~h}$, which corresponds to four months on supermarket shelves. Improvement was also 
shown for the appearance of the sample with added extracted ethyl acetate compounds at 168h. Table 2 presents the results of the organoleptic evaluation.

In relation to the control (original beer sample with added ascorbic acid), significant differences $(P<0.05)$ were found regarding appearance with the samples with $75 \mathrm{mg} \mathrm{EBH}$ and $15 \mathrm{mg} \mathrm{Fdcm}$ added, regarding flavor with the samples with $75 \mathrm{mg}$ Faq, $15 \mathrm{mg}$ Fdcm and $45 \mathrm{mg}$ EBH added, regarding aroma with the samples with $45 \mathrm{mg}$ Faq and $15 \mathrm{mg} F \mathrm{fcm}$ added and regarding overall acceptance with the samples with $45 \mathrm{mg}$ Faq, $75 \mathrm{mg}$ Faq and 15 mg Fdcm added.

Table 1. Results of the percentage of beta carotene oxidation with each beer sample

\begin{tabular}{lcccccc}
\hline & 42h (\%) & $\mathbf{1 2 6 h}(\%)$ & $\mathbf{1 6 2 h}(\%)$ & $\boldsymbol{P}$ vs C+ & $\boldsymbol{P}$ vs CCL & $\boldsymbol{P}$ vs CSL \\
\hline C+ & 0.00 & 0.50 & 0.00 & - & 0.0775 & 0.0627 \\
CCL & 0.30 & 0.76 & 0.56 & 0.0775 & - & 0.3899 \\
CSL & 0.30 & 0.75 & 0.75 & 0.0627 & 0.3899 & - \\
EBH 15 mg & 0.26 & 0.70 & 0.57 & 0.0901 & 0.4601 & 0.3371 \\
EBH 45 mg & 0.12 & 0.57 & 0.33 & 0.2291 & 0.2808 & 0.1302 \\
EBH 75 mg & 0.15 & 0.54 & 0.42 & 0.1863 & 0.3083 & 0.1455 \\
Faq 15 mg & 0.15 & 0.34 & 0.45 & 0.2398 & 0.2765 & 0.0871 \\
Faq 45 mg & 0.20 & 0.32 & 0.48 & 0.2097 & 0.2271 & 0.0965 \\
\hline Faq 75 mg & 0.20 & 0.31 & 0.45 & 0.2231 & 0.1101 & 0.0840 \\
Fhex & 0.19 & 0.37 & 0.50 & 0.1900 & 0.2271 & 0.1156 \\
Fdcm & 0.23 & 0.35 & 0.33 & 0.2342 & 0.0810 & 0.0636 \\
Fact & 0.03 & 0.37 & 0.23 & 0.4170 & 0.0586 & $\mathbf{0 . 0 4 7 8}$ \\
Fbut & 0.14 & 0.34 & 0.30 & 0.3134 & 0.0519 & 0.0519 \\
\hline
\end{tabular}

C+: positive control (BHT 1000 ppm); CCL: control of beer without addition of propolis subjected to light chamber; CSL: control of beer without addition of propolis maintained and $6 \circ \mathrm{C}$ in the dark; $\mathrm{EBH}$ : Beer added of $15 \mathrm{mg}(0.05 \mathrm{~g} / \mathrm{L}), 45 \mathrm{mg}(0.15 \mathrm{~g} / \mathrm{L})$ or $75 \mathrm{mg}(0,25 \mathrm{~g} / \mathrm{L})$ hydro alcoholic propolis extract; Faq: Beer added of $15 \mathrm{mg}$ $(0.05 \mathrm{~g} / \mathrm{L}), 45 \mathrm{mg}(0.15 \mathrm{~g} / \mathrm{L})$ or $75 \mathrm{mg}(0.25 \mathrm{~g} / \mathrm{L})$ propolis aqueous fraction; Feh: beer added of hexane fraction $(0.05 \mathrm{~g} / \mathrm{L})$; Fdcm: beer added of dichloromethane fraction $(0.05 \mathrm{~g} / \mathrm{L})$, Fact: beer added of ethyl acetate fraction $(0.05 \mathrm{~g} / \mathrm{L})$; Fbut: beer added of butanol fraction $(0.05 \mathrm{~g} / \mathrm{L})$ 
Table 2. Mean (standard deviation) of the scores attributed to the Appearance, Flavor, Aroma and Global Acceptance aspects of the beer samples incubated in a fluorescent light chamber for 8, 8, 9 and $126 \mathrm{C}$ added with the $\mathrm{EBH}$ fractions

\begin{tabular}{|c|c|c|c|c|c|c|c|c|c|c|c|c|c|c|c|c|}
\hline & Appearance & & & & Flavor & & & & Aroma & & & & $\begin{array}{l}\text { Global } \\
\text { Acceptance }\end{array}$ & & & \\
\hline $\begin{array}{l}\text { Fraction / } \\
\text { Mean } \\
\text { grade (SD) }\end{array}$ & $42 \mathrm{~h}$ & $84 \mathrm{~h}$ & $126 \mathrm{~h}$ & $168 \mathrm{~h}$ & $42 \mathrm{~h}$ & $824 \mathrm{~h}$ & $126 \mathrm{~h}$ & $168 \mathrm{~h}$ & $42 \mathrm{~h}$ & $84 \mathrm{~h}$ & $126 \mathrm{~h}$ & $168 \mathrm{~h}$ & $42 \mathrm{~h}$ & $84 \mathrm{~h}$ & $126 \mathrm{~h}$ & $168 \mathrm{~h}$ \\
\hline $\mathrm{EBH} 15 \mathrm{mg}$ & $6.5(1.38)$ & $6.7(2.07)$ & $\begin{array}{c}6.5 \\
(1.22)\end{array}$ & $7.0(2.28)$ & $\begin{array}{c}7.5 \\
(1.52)\end{array}$ & 6.5 (1.05) & $7.2(0.98)$ & $\begin{array}{c}6.5 \\
(2.43)\end{array}$ & $\begin{array}{c}8.2 \\
(0.98)\end{array}$ & $7.0(1.55)$ & $7.5(0.55)$ & $7.0(1.9)$ & $7.33(1.03)$ & $6.83(1.47)$ & $\begin{array}{c}6.83 \\
(0.75)\end{array}$ & $\begin{array}{c}6.67 \\
(2.58)\end{array}$ \\
\hline $\mathrm{EBH} 45 \mathrm{mg}$ & $7.0(0.63)$ & $6.2(2.04)$ & $6.0(0)^{1}$ & $6.5(2.07)$ & $\begin{array}{c}6.5 \\
(1.05)\end{array}$ & $5.3(1.37)$ & $5.2(0.41)^{1}$ & $\begin{array}{c}6.2 \\
(1.94)\end{array}$ & $\begin{array}{c}8.2 \\
(0.75)\end{array}$ & $6.3(1.03)^{2}$ & $5.8(0.41)^{1}$ & $\begin{array}{c}6.5 \\
(2.26)\end{array}$ & $7.3(1.03)$ & $5.2(1.33)^{2}$ & $5.8(0.75)^{1}$ & $6.7(1.97)$ \\
\hline $\mathrm{EBH} 75 \mathrm{mg}$ & $6.2(1.60)$ & 6.5 (1.76) & $\begin{array}{c}7.2 \\
(0.75)\end{array}$ & 7.0 (1.75) & $\begin{array}{c}6.8 \\
(1.33)\end{array}$ & 6.5 (1.38) & $2.0(1.26)^{1}$ & $\begin{array}{c}7.0 \\
(1.55)\end{array}$ & $\begin{array}{c}7.7 \\
(1.03)\end{array}$ & $7.0(1.1)$ & $4.3(2.07)^{1}$ & $\begin{array}{c}7.0 \\
(0.63)\end{array}$ & $7.0(1.1)$ & $6.3(1.51)$ & $2.8(1.72)^{1}$ & $7.0(1.1)$ \\
\hline Faq 15 mg & $7.3(0.52)$ & 7.7 (1.37) & $\begin{array}{c}8.0 \\
(0.63)\end{array}$ & $7.7(2.34)$ & $\begin{array}{c}7.7 \\
(1.03)\end{array}$ & 7.7 (1.03) & 6.7 (1.51) & $\begin{array}{c}7.8 \\
(1.94)\end{array}$ & $\begin{array}{c}8.0 \\
(0.89)\end{array}$ & $7.0(1.1)$ & $7.3(0.52)$ & $\begin{array}{c}7.8 \\
(1.60)\end{array}$ & $7.7(0.52)$ & $7.5(0.84)$ & $6.8(0.98)$ & 7.7 (1.97) \\
\hline Faq $45 \mathrm{mg}$ & $7.5(0.84)$ & $7.8(0.98)$ & $\begin{array}{c}7.7 \\
(1.75)\end{array}$ & $6.2(1.94)$ & $\begin{array}{c}7.0 \\
(0.89)\end{array}$ & $7.2(1.2)$ & $7.2(1.47)$ & $\begin{array}{c}5.8 \\
(1.72)\end{array}$ & $\begin{array}{c}6.3 \\
(0.82)\end{array}$ & $7.2(1.17)$ & $7.8(0.41)^{1}$ & $\begin{array}{c}5.7 \\
(1.86)\end{array}$ & $7.2(0.41)$ & $7.2(1.17)$ & $7.7(1.03)$ & $5.3(2.42)$ \\
\hline Faq $75 \mathrm{mg}$ & $7.2(0.75)$ & $8.0(0.89)$ & $\begin{array}{c}7.8 \\
(0.41)\end{array}$ & $7.7(1.51)$ & $\begin{array}{c}6.3 \\
(1.51)\end{array}$ & $7.2(0.75)$ & $6.5(0.84)$ & $\begin{array}{c}7.7 \\
(1.21)\end{array}$ & $\begin{array}{c}7.3 \\
(1.37)\end{array}$ & $7.2(1.33)$ & $7.8(0.75)$ & $\begin{array}{c}8.0 \\
(0.89)\end{array}$ & $6.8(0.40)$ & $7.5(0.84)$ & $7.3(0.52)$ & $7.3(1.21)$ \\
\hline $\begin{array}{l}\text { Fhex } \\
\text { mg }\end{array}$ & $7.8(0.41)$ & $7.2(0.98)$ & $\begin{array}{c}7.2 \\
(1.17)\end{array}$ & $6.2(2.64)$ & $\begin{array}{c}7.5 \\
(1.38)\end{array}$ & 6.7 (1.86) & $2.5(2.35)^{1}$ & $\begin{array}{c}5.8 \\
(2.04)\end{array}$ & $\begin{array}{c}8.0 \\
(0.63)\end{array}$ & $7.3(0.52)$ & $4.0(0.89)^{1}$ & $\begin{array}{c}6.0 \\
(2.61)\end{array}$ & $8.0(0.89)$ & $7.0(1.1)$ & $3.0(2.0)^{1}$ & $5.7(2.50)$ \\
\hline $\begin{array}{ll}\mathrm{Fdcm} & 15 \\
\mathrm{mg} & \end{array}$ & $5.2(1.60)$ & $7.7(1.03)^{2}$ & $\begin{array}{c}5.8 \\
(1.47)\end{array}$ & $6.3(2.25)$ & $\begin{array}{c}6.0 \\
(0.63)\end{array}$ & $7.7(0.52)^{2}$ & $5.0(1.79)$ & $\begin{array}{c}5.0 \\
(2.68)\end{array}$ & $\begin{array}{c}6.2 \\
(0.75)\end{array}$ & $7.8(0.41)^{2}$ & $5.0(1.1)$ & $\begin{array}{c}6.5 \\
(1.97)\end{array}$ & $5.8(0.98)$ & $\begin{array}{c}7.8(0.41) \\
)^{2}\end{array}$ & $5.2(1.47)$ & $5.5(2.17)$ \\
\hline Fact $15 \mathrm{mg}$ & $7.5(0.55)$ & $6.7(0.82)$ & $\begin{array}{c}7.5 \\
(1.22)\end{array}$ & $8.5(0.84)^{3}$ & $\begin{array}{c}7.2 \\
(1.17)\end{array}$ & 6.2 (1.47) & $5.3(1.86)^{4}$ & $\begin{array}{c}7.7 \\
(1.03)\end{array}$ & $\begin{array}{c}6.7 \\
(1.51)\end{array}$ & $7.0(1.26)$ & $8.2(0.98)$ & $7.0(2.0)$ & 7.2 (1.17) & $6.3(1.21)$ & $6.3(1.86)$ & $7.7(1.03)$ \\
\hline $\begin{array}{ll}\text { Fbut } & 15 \\
\mathrm{mg} & \end{array}$ & $7.7(0.82)$ & 7.2 (1.17) & $\begin{array}{c}8.3 \\
(0.82)\end{array}$ & $6.8(1.60)$ & $\begin{array}{c}7.5 \\
(0.84)\end{array}$ & $6.2(1.33)$ & $6.2(2.14)$ & $\begin{array}{c}6.0 \\
(2.37)\end{array}$ & $\begin{array}{c}7.5 \\
(0.55)\end{array}$ & $7.0(1.1)$ & $6.2(1.72)$ & $\begin{array}{c}6.7 \\
(2.25)\end{array}$ & $7.8(0.98)$ & $6.3(0.82)$ & $6.2(1.47)^{1}$ & $6.3(2.16)$ \\
\hline Control & $9.0(0.89)$ & - & - & - & $\begin{array}{c}8.0 \\
(0.89)\end{array}$ & - & - & - & $\begin{array}{c}8.0 \\
(0.89)\end{array}$ & - & - & - & $8.3(1.03)$ & - & - & - \\
\hline
\end{tabular}

$\mathrm{Fc}$ (dichloromethane fraction), Fact (ethyl acetate fraction), and Fbut (Butanol fraction), in relation to the control sample (beer sample without propolis extract with ascorbic acid). 1 P < $0.05: 126$ h vs 42 h; 2 P < < .05: 82 h vs 42 h; 3 P < 0.05 : 168 h vs 42 h; $4 \mathrm{P}<0.05: 126$ h vs 168 h. 


\section{Discussion}

The fluorescent light test is an accelerated simulation of the storage conditions of products on supermarket shelves. This approach is effective because the short visible wavelength emitted makes it possible to observe almost all damage to a product and the durability of the exposed material. Consequently, tests with fluorescent lamps confine the emission of light only to the portion of the radiation spectrum that corresponds to the visible spectrum. ${ }^{7}$

Beers of low fermentation are characterized by being fermented at temperatures from 3.3 to $13{ }^{\circ} \mathrm{C}$. Beers in general have a lot of contact with oxygen during their manufacturing process. Those of low fermentation, due to their production temperature characteristics, lose the natural protection of live yeasts on oxidation processes from pasteurization and therefore require the addition of antioxidants for preservation. Therefore, we chose these beers for our experiments. In contrast, high fermentation beers, fermented at temperatures between 12 and $15 \circ \mathrm{C}$, are often unpasteurized, which keeps

the yeasts alive and contributes to their preservation against oxidative stress; thus, these do not require additional antioxidants. ${ }^{27}$

After exposing the beer samples, both with and without added propolis-extracted compounds, to the fluorescent light, they were tested for their residual antioxidant potential using the beta carotene method, as well as using sensory analysis.

We observed that all the extracts presented the inhibition of beta-carotene oxidation statistically indistinctly from BHT, without altering the organoleptic characteristics of the beer. Notably, the dichloromethane fraction showed a significant inhibition of oxidation, compared to the sample of beer kept under refrigeration and under light, as it was able to improve the perception of beer at $84 \mathrm{~h}$ of incubation.
Extracts of this propolis type have been found to contain phenols, tannins, flavones, flavonols, xanthones and catechins, as well as saponins, triterpenes and steroids. ${ }^{22}$ Terpenes have already been studied as antioxidants capable of stopping the free radical cascade formation. ${ }^{20}$ Compared to commercially available standards of 14 phenolic substances, quercetin, epigallocatechin, $\mathrm{p}-\mathrm{OH}$-benzoic acid, epigallocatechin gallate and coumaric acid could be identified by HPCL in the hydroalcoholic extract, $^{22}$ as could catechin, epicatechin, aromadendrin, naringenin, pinocembrin and $\mathrm{p}$ coumaric acid by HPCL-ESI-MS/MS. ${ }^{23}$ The chemical and compound interactions resulting from the addition of propolis to beer deserve to be better studied, especially regarding terpene content.

Our search of the PubMed and Scielo.org databases discovered no works that scientifically evaluated the potential of adding propolis to beer for preservation. Some researchers ${ }^{28}$ have observed that the addition of ethanolic extract produced an increase in the antioxidant potential of beer, without altering the organoleptic characteristics of Golden Ale (high fermentation) type beer.

According to data from October 2016 of the Association of Micro Breweries of Santa Catarina (SC), Brazil - ACASC, the number of brands producing the beverage has tripled in 4 years and production exceeds 1 million liters/month in the country. In 2016, investments in SC were $\mathrm{R} \$ 22$ million. With this volume of production, we can estimate an average volume of sales to the consumer on the order of $\mathrm{R} \$ 360$ million a year. Also, in the honey agribusiness, thanks to the high quality produced, SC became the largest exporter in Brazil in the 2017 harvest and remains in the third position in the national ranking of producers. Half of the honey from SC is exported and $42 \%$ of the total produced has organic certification.

In the next ten years, the world market will increase its honey demand by 170 thousand tons; currently, Brazil only produces $10 \%$ of its productive potential. ${ }^{29}$ There are about 450 thousand hives distributed among 30 thousand 
beekeepers, who gather in 60 associations linked to the Federation of Associations of Beekeepers of Santa Catarina (Faasc). At the end of each harvest, the sum of these small quantities reaches volumes that, in the State, move around $\mathrm{R} \$ \mathbf{3} 30$ million. $^{30}$ For those engaged in the activity, the hives also supply pollen, propolis, royal jelly, wax and apitoxin. Recognized primarily for alternative therapies and by the international pharmaceutical industry as a powerful healing and antibacterial agent, propolis is considered underutilized in Brazil - the eighth largest producer in the world, with over 150 tons per year. The country has not yet discovered the full potential of propolis for food and medicine. While our companies in the sector are micro and small, with average monthly sales of about $\mathrm{R} \$ 20$ thousand, Japan, whose domestic market is encouraged by Brazilian companies, annually moves US\$ 300 million. ${ }^{31}$

\section{Conclusion}

The use of propolis as a preservative for Brazilian craft beers, once well-founded, can add significant value in the production chain of beekeeping in the State and in the country. Notably, the extracted dichloromethane compounds from this type of propolis appear to be promising and the chemical interactions resulting from the addition of propolis to beer deserve further study.

\section{Acknowledgment}

We thank the Das Bier brewery (Blumenau, SC, Brazil), especially Mr. Leandro Schmitt, for supplying the beer samples used in this work.

\section{References}

${ }^{1}$ Stewart, G. G.; Beer Shelf Life and Stability, 2nd ed. Woodhead Publishing: New York, 2016. [CrossRef]

${ }^{2}$ Lopes C. M. M.; Dissertação de Mestrado,
Universidade do Minho, Portugal, 2013. [Link]

${ }^{3}$ Nimubona, D.; Blanco, C. A.; Caballero, I.; Rojas, A.; Andrés-Iglesias, C. An approximate shelf life prediction of elaborated lager beer in terms of degradation of its iso- $\alpha$-acids. Journal of Food Engineering 2013, 116, 1. [CrossRef]

${ }^{4}$ Rakcejeva, T.; Skorina, V.; Karklina, D.; Skudra, L. ASLT Method for beer accelerated Shelf-life determination. International Journal of Nutrition and Food Engineering 2013, 7, 2. [Link]

${ }^{5}$ Kilcast, D.; Subramaniam, P.; The stability and shelf-life of food, 1 ed. Woodhead Publishing: New York, 2010. [Link]

${ }^{6}$ Dušekm, M.; Olšovská, J.; Krofta, K.; Jurková, M.; Mikyška, A. Qualitative Determination of $\beta$-Acids and Their Transformation Products in Beer and Hop Using HR/AM-LC-MS/MS. Journal of Agricultural and Food Chemistry 2014, 62, 31. [CrossRef]

${ }^{7}$ Steenackers, B.; De Cooman, L.; De Vos. D. Chemical transformations of characteristic hop secondary metabolites in relation to beer properties and the brewing process: A review. Food Chemistry 2015, 172, 742. [CrossRef]

${ }^{8}$ Giménez, A.; Ares, F.; Ares, G. Sensory shelflife estimation: A review of current methodological approaches. Food Research International 2012, 49, 311. [CrossRef]

${ }^{9}$ Hough, G.; Garitta, L. Methodology for sensory shelf-life estimation: a review. Journal of Sensory Studies 2012, 27, 137. [CrossRef]

${ }^{10}$ Valero, A.; Carrasco, E.; García-Gimeno, R.; Principles and Methodologies for the Determination of Shelf-Life in Foods. In: Trends in Vital Food and Control Engineering, Eissa, A. H. A. ed., IntechOpen: Rijeka, 2012, p. 3-42. [Link]

${ }^{11}$ Kuropatnicki, A. K.; Szliszka, E.; Krol, W. Historical Aspects of Propolis Research in Modern Times. Evidence-Based Complementary and Alternative Medicine 2013, 2013, Article ID 964149. [CrossRef]

${ }^{12}$ Sforcin, J. M. Biological Properties and Therapeutic Applications of Propolis. Phytotherapy Research 2016, 30, 6. [CrossRef] [PubMed]

${ }^{13}$ Nunes, C. A.; Guerreiro, M. C. Characterization of Brazilian green propolis throughout the seasons by headspace GC/MS and ESI-MS. Journal of the Science of Food and Agriculture 2012, 92, 2. [CrossRef] [PubMed] 
${ }^{14}$ Naramoto, K.; Kato, M.; Ichihara, K. Effects of an Ethanol Extract of Brazilian Green Propolis on Human Cytochrome P450 Enzyme Activities in Vitro. Journal of Agricultural and Food Chemistry 2014, 62, 46. [CrossRef] [PubMed]

${ }^{15}$ Pereira, A. dos S.; Seixas, F. R. M. S.; de Aquino Neto, F. R. Própolis: 100 anos de pesquisa e suas perspectivas futuras. Química Nova 2002, 25, 2. [CrossRef]

16 Salatino, A.; Teixeira E. W.; Negri, G.; Message, D. Origin and chemical variation of Brazilian propolis. Evidence-Based Complementary and Alternative Medicine 2005, 2, 1. [CrossRef] [PubMed]

17 Wang, Y. C.; Chen, S.; Yu, O. Metabolic engineering of flavonoids in plants and microorganisms. Applied Microbiology and Biotechnology 2011, 91, 4. [CrossRef] [PubMed]

${ }^{18}$ Nijveldt, R. J.; van Nood, E.; van Hoorn, D. E.; Boelens, P. G.; van Norren, K.; van Leeuven P. A. Flavonoids: a review of probable mechanisms of action and potential applications. American Journal of Clinical Nutrition 2001, 74, 4. [CrossRef] [PubMed]

19 Toreti, V. C.; Sato, H. H.; Pastore, G. M.; Park, Y. K. Recent Progress of Propolis for Its Biological and Chemical Compositions and Its Botanical Origin.

Evidence-Based Complementary and Alternative Medicine 2013, 2013, Article ID 697390. [CrossRef] [PubMed]

${ }^{20}$ Gonzalez-Burgos, E.; Gomez-Serranillos, M. P. Terpene Compounds in Nature: A Review of Their Potential Antioxidant Activity. Current Medicinal Chemistry 2012, 19, 31. [PubMed]

${ }^{21}$ Huang, S. A.; Zhang, C. P.; Wang, K.; Li, G. Q.; $\mathrm{Hu}, \mathrm{F}$. L. Recent Advances in the Chemical Composition of Propolis. Molecules 2014, 19, 12. [CrossRef] [PubMed]

22 dos Santos L.; Hochheim, S.; Boeder, A. M.; Kroger, A.; Tomazzoli, M. M.; Dal Pai Neto, R.; Maraschin, M.; Guedes, A.; de Cordova, C. M. M. Chemical characterization, antioxidant, citotoxic and antibacterial activity of propolis extracts and isolated compounds from the Brazilian native bees Melipona quadrifasciata and Tetragonisca angustula. Journal of Apicultural Research 2017, 56, 5. [CrossRef]

${ }^{23}$ Hochheim, s.; Guedes, A.; Faccin-Galhardi, F.; Rechenchoski, D. Z.; Nozawa, C.; Linhares, R. E; da Silva Filho, H. H.; Rau, M.; Siebert, D. A.; Micke, G.; de Cordova. C. M. M. Determination of phenolic profile by HPLC-ESI-MS/MS, antioxidant activity, in vitro cytotoxicity and antiherpetic activity of propolis from the Brazilian native bee Melipona quadrifasciata. Revista Brasileira de Farmacognosia 2019, 29, 339. [CrossRef]

${ }^{24}$ Banskota, A. H.; Tezuka, Y.; Kadota, S. Recent progress in pharmacological research of propolis. Phytotherapy Research 2001, 15, 7. [CrossRef] [PubMed]

${ }^{25}$ Instituto Adolf Lutz - IAL; Métodos físicoquímicos para análise de alimentos, 4a ed., IAL: São Paulo, 2008. [Link]

${ }^{26}$ Mokbel, M. S.; Hashinaga, F. Evaluation of the antioxidant activity of extracts from buntan (Citrus grandis Osbeck) fruit tissues. Food Chemistry 2006, 94, 4. [Link]

27 Silva, P. H. A; Faria, F. C. Avaliação da intensidade de amargor e do seu princípio ativo em cervejas de diferentes características e marcas comerciais. Ciência e Tecnologia de Alimentos 2008, 28, 4. [Link]

${ }^{28}$ Ulloa P. U.; Vidal, J.; Ávila, M. I.; Labbe, M.; Cohen, S.; Salazar, F. N. Effect of the Addition of Propolis Extract on Bioactive Compounds and Antioxidant Activity of Craft Beer. Journal of Chemistry 2017, 2017, Article ID 6716053. [CrossRef]

${ }^{29}$ Magalhães, A., SC terá safra recorde de mel em 2017. Available at: <http://www.correiootaciliense.com.br/geral sc-ter\%C3\%A1-safra-recorde-de-mel-em2017-1.1971308>. Accessed in 02 april 2019.

${ }^{30}$ Freitas, C. A., Apicultura: Doce e lucrativo negócio. Revista Agropecuária Catarinense 2011, 24, 2. [Link]

${ }^{31}$ Marques, C., CIÊNCIA: Patente torna própolis mais competitiva. Available at: <http://www.bv.fapesp.br/namidia/noticia/152 58/ciencia-patente-torna-propoliscompetitiva/>. Accessed in: 02 april 2019. 